$\mathrm{Oz}$

Volume 12

Article 5

$1-1-1990$

\title{
(Almost) Square with the World
}

Donald J. Watts

Carol Martin Watts

Follow this and additional works at: https://newprairiepress.org/oz

(c) (i) $\Theta(9$

This work is licensed under a Creative Commons Attribution-Noncommercial-No Derivative Works 4.0 License.

\section{Recommended Citation}

Watts, Donald J. and Watts, Carol Martin (1990) "(Almost) Square with the World," Oz: Vol. 12.

https://doi.org/10.4148/2378-5853.1193

This Article is brought to you for free and open access by New Prairie Press. It has been accepted for inclusion in Oz by an authorized administrator of New Prairie Press. For more information, please contact cads@k-state.edu. 


\section{(Almost) Square With the World}

Donald J. Watts

Carol Martin Watts

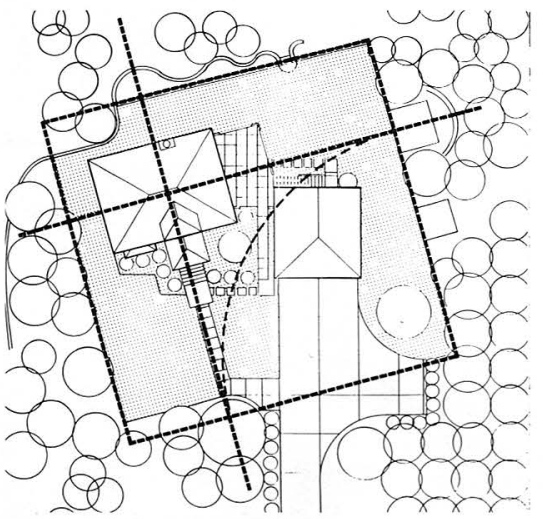

Memories of two traditions, both emphasizing being "square with the world," are embedded in our own house in Manhattan, Kansas, finished in the spring of 1989. The most immediate tradition is that of the Midwest foursquare farmhouse. Equally important to us, because of our many years of research and experience, is the tradition of Roman architecture and urbanism. Through interpretation and adaptation these memories have been applied to our house using current materials and construction techniques.

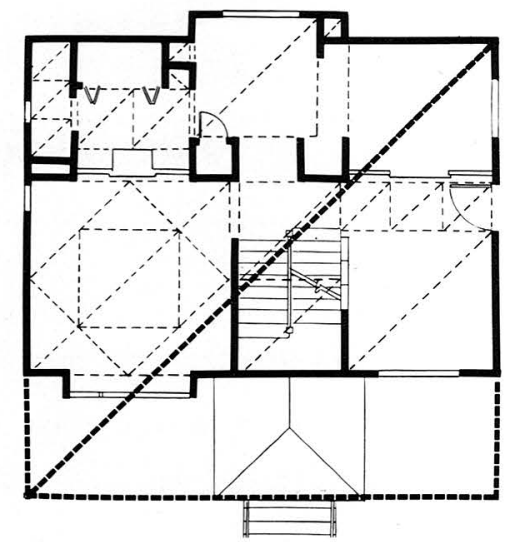

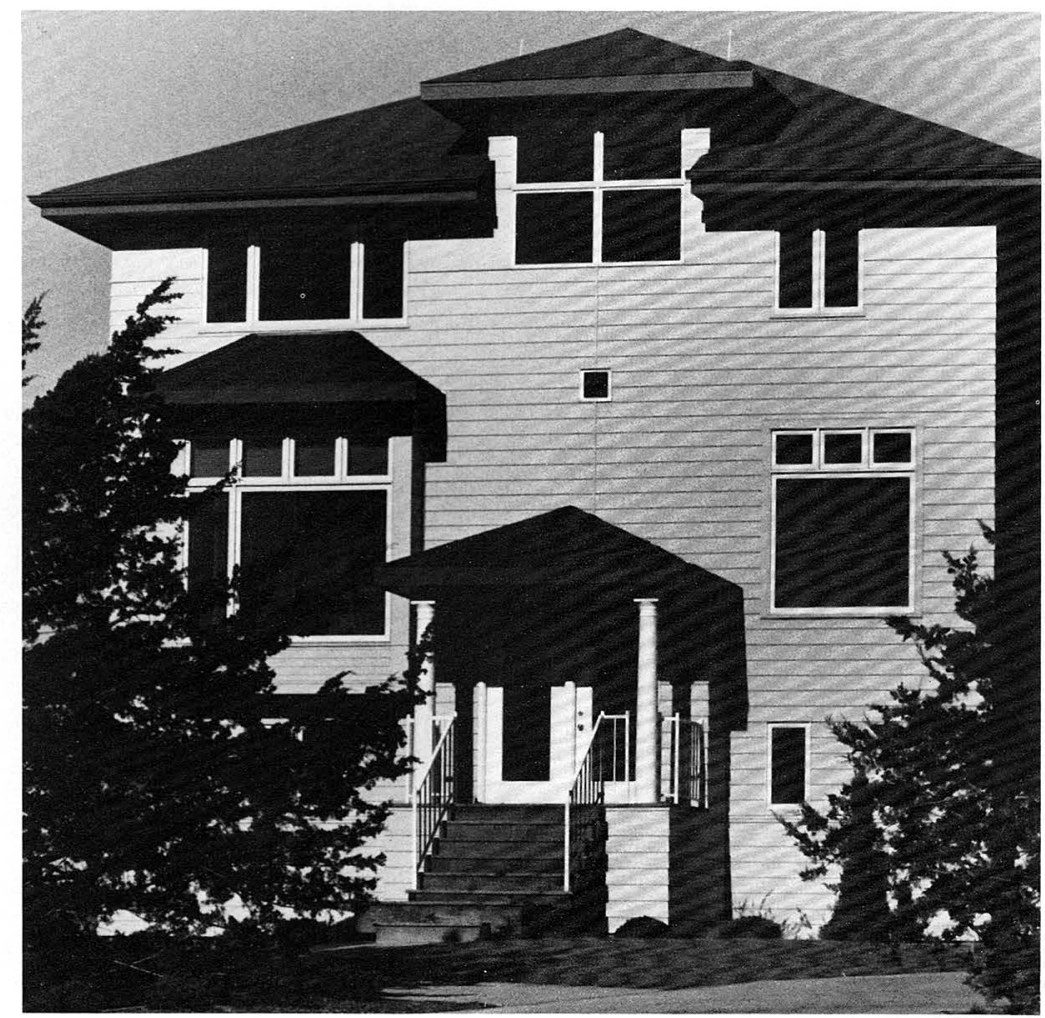

The late 19th and early 20th century midwestern Foursquare or Prairie house is indigenous to the American prairie. In a world of distant horizons, orientation by the sun and compass is imbedded in the thought, language and rituals of the frontier. The popular phrase "square with the world" reflects this common worldview. Prior to mechanized agriculture, farmhouses were typically centered within a section of land framed by a one-mile grid of country roads. Before the introduction of contour plowing, fields were plowed in rows square with the world. In Roman times as well, the centuriation of farmlands and similiar canonic ordering of nearby towns comprehensively connected man, land, and settlement to the larger world.

Orientation, centering, and geometry are three closely related principles essential to the design of our house. Orientation to the cardinal points and to the path of the sun is of great importance. It is through observation of changing light patterns at different times of day and seasons that one can be oriented with respect to both

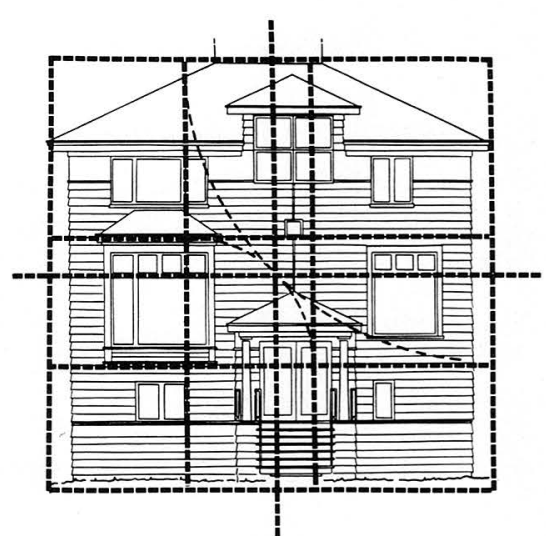

time and place. Manhattan, Kansas is ordered by a grid oriented to the cardinal points. House and garage are treated as separate entities oriented to different needs. The garage and driveway align with the city grid. The house responds to the particular horizon of the site. Facing fifteen degrees east of due south, the house is almost square with the world. Oriented towards a distant view of the Konza Prairie, the house also takes better advantage of morning sun.

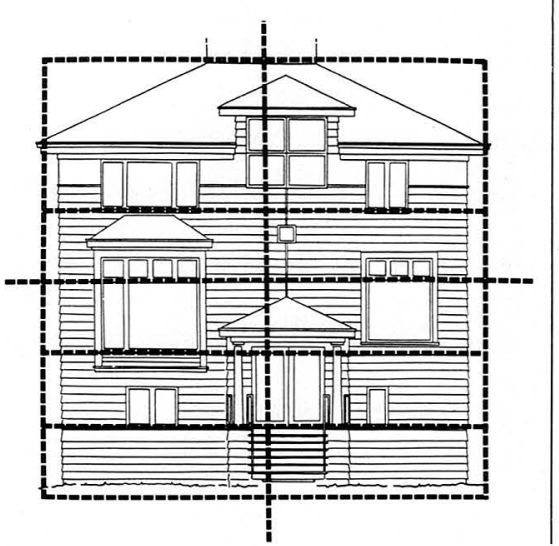


The concept of centering, of establishing domains, at a variety of scales, is also im portant in both the foursquare and Roman traditions. Reinforcement of centering occurs through the use of layers of encirclement which articulate particular relationships between the center and its surroundings. The house promotes an outward view from a tranquil and secure center

Related to both orientation and centering is the geometry of the square. Square with the world has direct geometric connotations in the traditions of vernacular and Roman architecture. We wanted to experi-

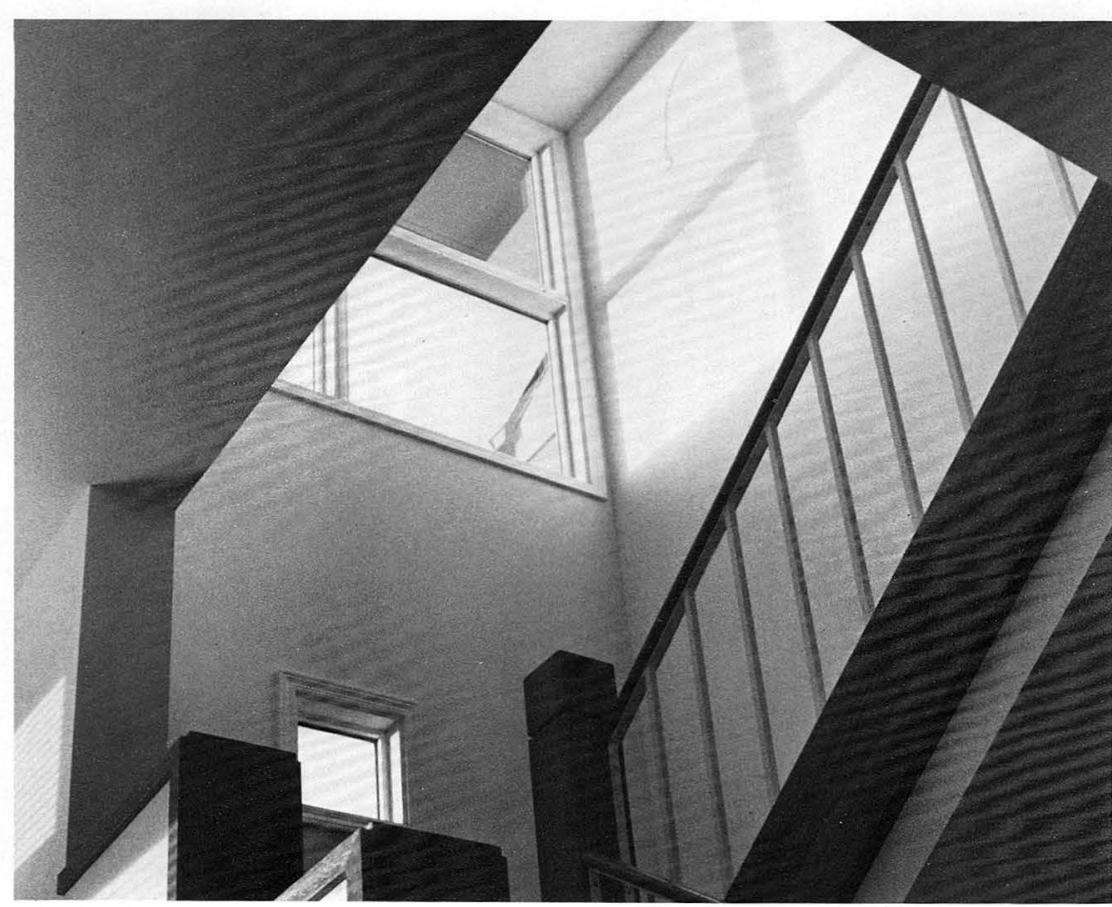

ment with such geometry in our own house design. The square is a centered form which can be oriented with respect to the world. It has two axes, and is both directional and centered at the same time. The square provides a unified frame of reference which can be subdivided in ways which insure the commensurability of its parts. The square, and divisions of the square, permeate many scales of the design of the house

The most forthright single-story vernacular foursquare houses have a room in each corner and partitions at the cross- axes of the square plan. A central masonry chimney projects through the pyramidal peak of the roof. In contrast to this use of a central mass, the Roman domus uses the atrium as a central space. Crossaxes are developed as visual corridors and the vertical axis is marked by the frame of the compluvium opening in the roof and its reflection as an impluvium recessed within the atrium floor plane. Similar patterns of spatial ordering can also be found in Roman urbanism, where the crossing of cardo and decumanus is marked by either a significant space or monument.

Qualities of these traditions are synthesized within the Manhattan house. On each of the three floors of the house the primary paths of movement occur along the crossaxes of the plan. The geometry of the house and site reinforces orientation and centering. As one approaches the formal entry along the line of the north-south axis, one sees through the geometrical center of the house mass to view the tree-topped hill beyond to the north. Arrival at the second floor stair landing places one at the intersection of two visual axes with directed views to the horizons.

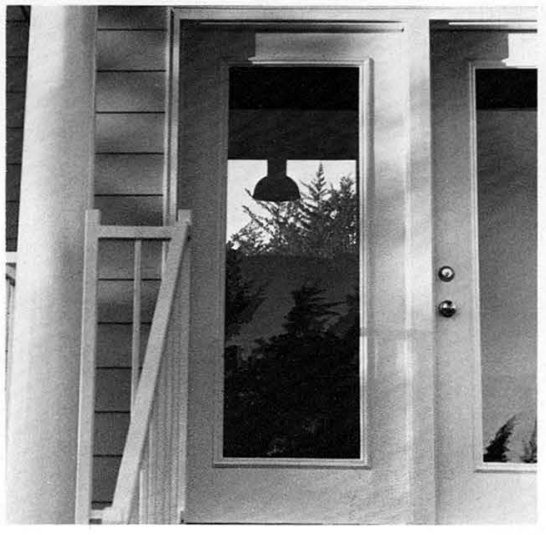

The disposition of rooms combines the foursquare strategy of corner rooms with the insertion of a vertical stair tower in spired by qualities of the Roman domus. The vernacular dormer atop the stair tower serves as a light well, analogous to the atrium as the material means of creating a luminous center within the house. The large foursquare dormer window offers a connection to the sky and a view to the distant prairie.

The design utilizes regulating squares at successive scales beginning with the site and proceeding to the house plan, elevations, individual rooms, and details. Through proportional strategies similar to those of the Roman domus, areas of major rooms are simple ratios of the master regulating square.

As with the Roman decumanus and the medieval street, the principal east-west partition of our second floor serves as a datum for gathering and ordering the in terface of public/social and private/family activity. Like the earlier streets the daily

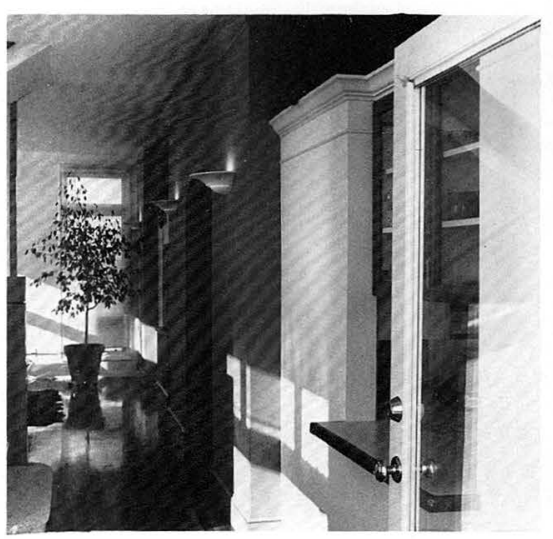

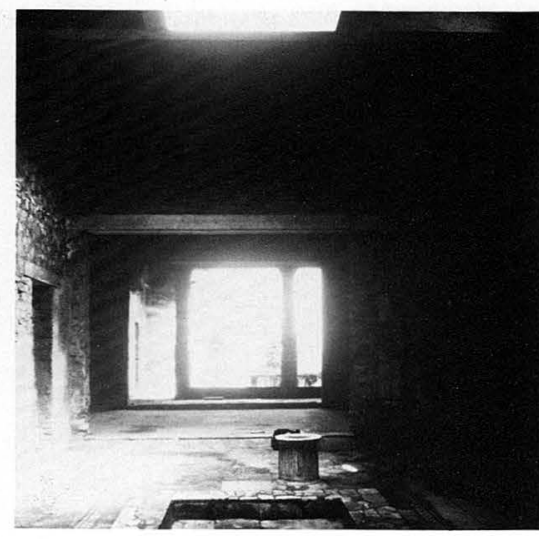

and seasonal patterns of light and shadow upon this wall marks the passage of time and provides a clear sense of orientation.

The geometry of the square and its commensurable subdivision serves to structure the orientation, enclosure and centering of the design. In the larger sense it serves to reflect the spatial qualities of the environs and represents a particular way of being between earth and sky. Traditional methods of making temporal and timeless connections to the larger world are joined by those of today and provisions for the future. Opposite the dormer view of the distant prairie lies the collective memory of our slide collection. Opposite the large bay window of the living room is the television/VCR cabinet placed in the wall of the house decumanus and articulated like a Roman shrine. Connections to today's world also come from mass communications and memories of our ancestors are now stored on video tape. Within the vertical spine of the house is an empty conduit for fiber optic cable or other connections in the future

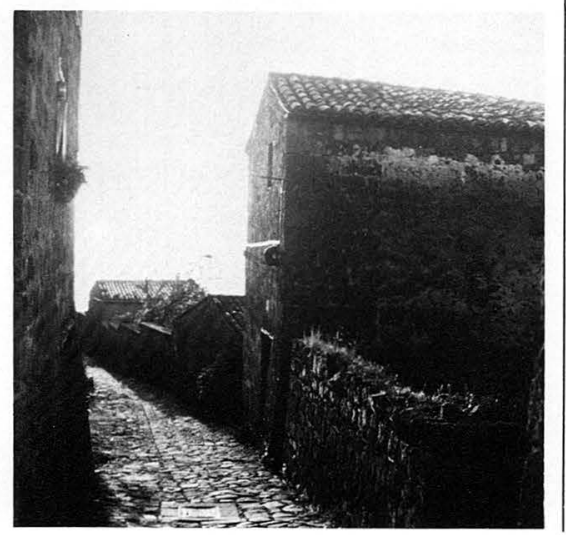

